\title{
Online Impulse Buying Behaviour: Case Study On Users Of Tokopedia
}

\section{Zuhdan Ady Fataron}

Faculty of Islamic Economics and Business, Islamic State University of Walisongo, Semarang, Indonesia

\section{A R T I C L E I N F O}

Article history:

Received 06 Desember 2019

Received in revised form 16 Januari 2020

Accepted 16 Januari 2020

\section{Keywords:}

Electronic Quality Service, Electronik

Trust, Customer Satisfaction

\begin{abstract}
A B S T R A C T
This article aims to find out the phenomenon of impulsive buying which is influenced by the ease of use and usefulness of information technology that mediates the pleasure of shopping, in this case the writer chooses tokopedia as the object of the research. Unplanned buying behavior is an interesting phenomenon to examine because it is potential for developing market share. The sample determination method used was 149 respondents. The population in this study is Tokopedia online shop users. Data analysis technique uses descriptive analysis, which is to obtain a picture of the respondent's tendency to answer, and inferential analysis to test the model developed, while the analysis technique used is Structural Equation Modeling (SEM). The result shows that the ease of use and usefulness of technology has a positive effect in supporting shopping pleasure, while shopping pleasure can explain the factors that influence impulsive purchases.
\end{abstract}

\section{A B S T R A K}

Artikel ini bertujuan untuk mengetahui fenomena pembelian impulsif yang dipengaruhi kemudahan penggunaan dan kemanfaatan teknologi informasi yang memediasi kenikmatan berbelanja, dalam hal ini penulis memilih tokopedia sebagai objek penelitian. Perilaku pembelian secara tak terencana merupakan fenomena yang menarik untuk di kaji karena merupakan potensi berkembangnya pangsa pasar. Metode penentuan sempel yang di gunakan sebanyak 149 responden. Populasi dalam penelitian ini adalah pengguna online shop Tokopedia. Teknik analisis data menggunakan analisis deskriptif yaitu untuk memperoleh gambaran kecenderungan jawaban responden, dan analisis inferensial untuk menguji model yang dikembangkan, adapun Teknik analisis yang digunakan menggunakan Structural Equation Modeling (SEM). Hasil pengujian yang dilakukan menunjukan bahwa kemudahan penggunaan dan kemanfaatan teknologi memberikan efek positif dalam menunjang kenikmatan berbelanja, sedangkan kenikmatan berbelanja dapat menjelaskan faktor yang mempengaruhi pembelian impulsive.

\footnotetext{
*Corresponding author.email: zuhdan_ady_fataron@walisongo.ac.id http://dx.doi.org/10.21580/jdmhi.2019.1.1.4762
} 


\section{Introduction}

The behavior of buyers who often make unplanned purchases is an interesting phenomenon to study because producers and retailers are attractive market shares in the modern market. Consumers / buyers when shopping at the market / mall often make the decision to buy a product without any plans / spontaneous once they see the situation in the market, especially in the digital era such as now many online markets that consumers can choose with various advantages of each online market, this provides greater shopping potential for consumers who are not accustomed to making shopping lists. This behavior is known as impulse buying.

Impulse buying is buying behavior without planning and this behavior often occurs spontaneously and in a hurry. Impulse buying occurs when a consumer purchases an unplanned product and / or brand before entering the store, reading the offer catalog, see TV, online on WEB and so on. (Agung \& Sri, 2018). In other words, consumers do not care about rationality, so that purchasing decisions are decided spontaneously, this is because consumers are attracted by discounts or cash backs, free shipping promotions, the convenience of efficient online shopping, so this causes consumers to make purchases. (Hatane Semuel, 2007).

The development of today's technology is increasingly rapid, people are difficult to separate from electronic devices, they are spoiled with various facilities in a digital way, so that human activities have a more effective and efficient impact, in terms of ease of information, costs and time. This digital era emerged starting with the existence of the internet network, especially related to information technology. (Setiawan, 2017). By the development of the world of information technology, currently emerging online markets, each of which has a strategy in dominating the Indonesian market share, with the online market consumers now no longer need to shop at a physical store, from the consumer view they are facilitated in terms of shopping, consumers only need to access the internet through the gadgets they have, with just one click consumers can find information about the items they want. From the producer view, they are facilitated in terms of opening efficient shanties, no need to rent expensive shanties, producers only need to register for free to become a member through the online market they want, producers can display merchandise with just one click, and merchandise that producers display can be accessed throughout the world.

The benefits of technology and the ease of technology can be felt after the user gets feedback or after they use the technology. For example, activities felt more efficient compared to doing it manually. Unconsciously this will make a sense of comfort using technology, resulting in the desire to reuse or even the effects of addiction to use the technology. This phenomenon is utilized by many online trading sites and service providers such as Tokopedia, Bukalapak, Lazada and others. In the table below is presented in full the largest online buying and selling site in Indonesia.

Tabel 1. Online Shop Competition

\begin{tabular}{ll}
\hline \multicolumn{1}{c}{ Online Shop } & $\begin{array}{c}\text { Monthly Web } \\
\text { Visitors }\end{array}$ \\
\hline Tokopedia & 65.953 .400 \\
Shopee & 55.964 .700 \\
Bukalapak & 42.874 .100
\end{tabular}




\begin{tabular}{ll} 
Lazada & 27.995 .900 \\
Blibli & 21.395 .600 \\
JD ID & 5.524 .000 \\
Bhineka & 5.037 .700 \\
Sociolla & 3.988 .300 \\
Orami & 3.906 .400 \\
\hline
\end{tabular}

Source:

https://iprice.co.id/insights/mapofecommerce/index.htm

From the table above, it can be seen that the most popular online store in Indonesia, Tokopedia, can be seen from the number of web visitors each month. Tokopedia is rank at first with total visitors of $65,953,400$ in Shopee and Bukalapak. This indicates that the online store market share in Indonesia is quite large and attractive in the hearts of consumers in Indonesia. In online shopping, usually the first time a user does is look for information about the desired item for example about specifications, models, and prices. Ease and enjoyment / comfort factor in accessing online store sites play a major role in consumer purchasing decisions, special promos that are provided such as flash sales, cash back, discounts, this promo is one that causes consumers to shop unplanned. From the description above, researchers are interested in conducting research with the title " Online Impulse Buying Behaviour: Case Study On Users Of Tokopedia".

\section{Literature Review}

\section{Information Systems and Information Technology}

Bodnar and Hopwood (2006: 6), said information systems imply the use of technology with computers in organizations or companies that can provide information for those who need and users.
According to (Dr. Richardus Eko Indrajit, 2000) the definition of information is internationally agreed as a "result of data processing" which in principle has more value than the raw data. The computer as the first tool (forerunner) that can process data into information. The development of telecommunications technology is increasing rapidly, causing the world to feel increasingly narrow. From the description above we can conclude that information technology is a technology related to processing data into information and the process of channeling data / information within the boundaries of space and time.

\section{Ease and usefullness of Information Technology}

understanding ease of use is the degree to which a person believes that using a particular system is free from effort. The most important thing for the user is the amount of effort he spends to spend in using a system. (Davis, 1989)

The definition of user benefits is the degree to which a person believes that the use of a particular system will be able to improve the work performance of that person (Davis, 1989). Whereas Information Technology Utilization is a benefit expected by Information Technology users in carrying out their duties (Thompson, Higgins, \& Howell, 1991).

\section{Shopping Enjoyment}

The concept of enjoyment has been measured and defined as the level at which activities are perceived as the extent to which activities using a particular system are considered to provide pleasure and happiness in oneself, apart from how the performance consequences resulting from the use of the 
system (Davis in Shen, 2012)

Shopping pleasure is described as a hedonic attitude that is more experimental and related to how much pleasure consumers can get from a product (Batra \& Ahtola, 1991).

From some of the above understanding it can be concluded that shopping pleasure is a feeling of pleasure and happiness generated by consumers who come from consumers' hedonic attitudes in the process of shopping and using a product

\section{Online Impulse Buying}

impulse buying behavior or what is commonly called an unplanned purchase. Impulse buying can be interpreted as part of a condition called "unplanned purchase" or unplanned purchase (Purwa \& Yasa, 2015). According to (Mowen \& Minor, 2002) impulse buying is related to the act of buying that is not consciously recognized as a result of a consideration, or purchase intention that is formed before entering a store.

Impulse buying can basically consist of several kinds of characteristics including spontaneity (impulsive buying occurs unexpectedly), power, compulsion, and intensity (there is motivation to exclude other things and act immediately), excitement and stimulation (sudden buying desire arriving is often followed by emotions such as exciting, thrilling, or wild) and disregarded for consequences (the desire to buy can be something that cannot be denied) (Schiffman $\&$ Kanuk, 2008).

Some consumers in making decisions to buy are usually considered as rationality, consumers firstly identify and see service or product, then they compare and evaluate the profit or loss, and they finally choose the product / service that is most suitable. This online impulsive behavior is driven by spread of online platforms / channels so that consumers' access to products / services increases and makes payment and purchasing processes easier (Akram, Hui, Khan, Yan, \& Akram, 2018)

\section{Method, Data, and Analysis}

\section{Population and Sample}

The population and sample used in this study were conducted with a judgment sampling approach in which sampling was based on characteristics set against the target population elements that were adjusted to the objectives or research problem, namely: Respondents were students of Islamic state university of walisongo who only used the Tokopedia online site.

\section{Data Types and Sources}

Data needed in this study, obtained through primary sources, which refers to information obtained from the first hand by researchers relating to the variable of interest for the specific purpose of the study. Primary data obtained in this study are data about respondents' perceptions of the variable ease of use of technology, utilization of information technology, shopping pleasure and impulse buying.

\section{Method of collecting data}

Data collection was carried out through interviews using a questionnaire. The type of questions in the questionnaire are closed questions where respondents are asked to make choices between a series of alternatives given by the researcher (Sekaran, 2003) on a scale of $1-7$.

Operational Definitions and Indicators of Research Variables 
1. Ease of use of information technology.

Measurement of the ease of use of information technology variables adopted from research (Davis, 1989) which includes:

a. Site is easy to access.

b. b. The site is easy to learn.

c. c. The site is easy to use.

2. Variable Utilization of Information Technology.

Measurement of information technology utilization variables was adopted from research (Thompson et al., 1991) which included:

a. The use of the system can improve individual performance (improves job performance).

b. The use of the system is able to increase the level of individual productivity (increases productivity).

c. The use of the system can increase the effectiveness of individual performance (enhances effectiveness).

d. The use of the system is beneficial for individuals (the system is useful).

3. Shopping Enjoyment Variable.

The indicators used to measure the variables of shopping enjoyment were developed from research (Verhagen \& van Dolen, 2009), which include:

a. Interesting site to visit. b. The pleasure of finding products online.

c. Shopping online is fun.

4. Impulse Buying Variable.

Indicators used to measure the variable impulse buying were developed from research (Rook \& Fisher, 1995) which include:

a. Spontaneity or impulsive purchases occur unexpectedly.

b. Power Compulsion, and intensity or the motivation to put aside other things and act immediately.

c. Exitement and stimulation or sudden desire to buy, this is often followed by emotions such as exciting, thrilling, or wild.

d. Disregard for consequences or the desire to buy can be something that can not be denied.

The data analysis technique used to test the model and research hypotheses is carried out using the Structural Equation Modeling (SEM) approach.

Theoretical Thoughts And Hypothesis Formulation

Effect of Ease of Use of Information Technology on Shopping Enjoyment

Ease of use is a level where someone believes that using a system can be used easily without much effort (Davis, 1989). Ease of use is 
related to whether or not the site is used by prospective buyers. Usually prospective buyers will experience difficulties when first doing online shopping, and tend to discourage because of ignorance in online transactions.

If the use of an online shop is more difficult to compare the benefits gained from shopping online, then buyers will likely switch to another online shop site or switch to using conventional shopping. But if the online shop site is easier to use and provides many benefits, potential buyers will use the site to shop online. With this convenience prospective buyers will often use the online shop site. A system that is considered easy to use will automatically affect a person's behavior to use it (Succi and Walter) in (Nakayima, 2011).

H1: Ease of Use (X1) has a positive and significant effect on Shopping Enjoyment (X3).

\section{Effects of Information Technology Utilization on Shopping Enjoyment}

(Jogiyanto, 2005) defines perceived usefulness (perceived usefulness) as the extent to which a person believes that using a technology will improve work performance. Research shows that the construct of perceived usefulness influences positively and significantly on interest in using online transactions.

$\mathrm{H} 2$ : The technological usefulness (X2) has a positive and significant effect on shopping pleasure (X3)

\section{Effect of Ease of Use of Information Technology on Impulse Buying}

Research conducted (I Made Rendy Wicaksana, nd) mentions the ease of use of information technology and the perceived use of a positive effect on the intention to shop back on online trading sites, the intention of these potential buyers as a starting point for an interest in the products on the online site the shop. So it is probable that the prospective buyer will make the decision to make an unplanned purchase.

$\mathrm{H} 3$ : The ease of use of information technology (X1) has a positive influence on impulse buying

The Influence of Information Technology Utilization on Buying Impulses

Research conducted (Very Torgonda Tampubolon, 2018) states that the perception of utilization has a positive effect on the use of online applications. This explains that if an application provides positive benefits to the user, the user will continue to use the application repeatedly, so that when potential buyers find information about the desired product, potential buyers may be interested and make unplanned purchases.

In the study (I Made Rendy Wicaksana, n.d.) also mentioned that the perceived usefulness of the technology could affect the intention of prospective buyers to buy back on the online shop site. This can also be a factor causing impulse buying.

H4: The use of information technology (X2) has a positive effect on impulse buying.

\section{Effect of Shopping Enjoyment on Buying Impulses}

According to (Elizabeth Ferrell \& Beatty, 1998) shopping enjoyment is an effective condition to encourage impulsive buying. The study also concluded that someone who enjoys shopping will increase impulse buying intentions. Research conducted (Hart, Farrell, Stachow, Reed, \& Cadogan, 2007) 
mentions that the sex of a person also affects one's shopping enjoyment, this research also confirms that when a person feels the pleasure of shopping, then it tends to do shopping. The better store atmosphere provided by marketers, the more consumers will feel the shopping enjoyment when shopping (Bitner, 1992)

Based on research conducted (Purnasari \& Rastini, 2018) also states that shopping pleasure has a positive and significant effect on impulse buying, so that managers of online shop sites must provide comfort when consumers shop.

H5: Shopping pleasure (X3) has a positive effect on impulse buying.

\section{Result and Discussion}

The results of examining research model using SEM were described below:

\section{Confirmatory Analysis}

It was called the confirmatory factor analysis technique, because at this stage the model will confirm whether observed indicators could reflect analyzed factors. There was a basic test in confirmatory factor analysis, it was significance test for the factor weight. The significance of factor weight test was conducted to test whether an indicator could be used to confirm that the indicator could together explain a latent variable with other indicators. This test was carried out by using two stages of analysis, they were analysis of standardized regression weight value and factor weight analysis (Ferdinand, 2006):

1. Confirmatory Analysis of Exogenous Variable

Confirmatory analysis of exogenous variable was carried out to confirm whether observed indicators could reflect analyzed factors, it was exogenous variable which in this study was ease of use and technology utilization variable. To perform an confirmatory analysis of exogenous variable, there were two basic tests that must be carried out:

a. Goodness of Fit Test

The results of examining conformity of model in confirmatory factor analysis were presented in the following table.

Table 2- Exogenous Variable Feasibility Test Results

\begin{tabular}{lccc}
\hline Goodness of Fit Indeks & Cut off Value & Result & Model Evaluation \\
\hline Chi-Square $(\mathrm{df}=13)$ & Kecil $(<22,362)$ & 12,225 & Good \\
Probability & $\geq 0,05$ & 0,509 & Good \\
CMIN/DF & $\leq 2,00$ & 0,940 & Good \\
GFI & $\geq 0,90$ & 0,977 & Good \\
AGFI & $\geq 0,90$ & 0,950 & Good \\
TLI & $\geq 0,95$ & 1,004 & Good \\
CFI & $\geq 0,95$ & 1,000 & Good \\
RMSEA & $\leq 0,08$ & 0,000 & Good
\end{tabular}

Source: Primary data processed, 2019

Table 2 showed that Chi Square value = 12.225 with a significance level of 0.509 as well as other appropriateness values that meet fit criteria, so that it could be concluded that there was no difference between sample 
covariance matrix and estimated population covariance matrix which was accepted in which the mode is fit. So the model can overall be accepted to provide sufficient confirmation that showed that seven indicators used could reflect latent variable. analyzed, it was ease of use and technology utilization variable. b. Significance Test of Factor Weight

Significance test of factor weight was done to test whether a variable could be used to confirm that variable can together explain a latent variable with other variables. The required lambda value must reach 0.50 , if lambda value or factor loading is lower than 0,50 , it was regarded that the variable did not have same dimensions as other variables to explain a latent variable.

Table 3. Regression Weight of Exogenous Variable

\begin{tabular}{|c|c|c|c|c|c|c|}
\hline & & Std Estimate & Estimate & S.E. & C.R. & $\mathrm{P}$ \\
\hline $\mathrm{X} 1<\ldots$ & Ease & ,808 & 1,000 & & & \\
\hline $\mathrm{X} 2<\ldots$ & Ease & ,745 & ,857 & , 109 & 7,888 & $* * *$ \\
\hline X3 $<$ & Ease & ,705 & ,949 & , 130 & 7,276 & $* * *$ \\
\hline$X 4<\ldots$ & Technology Utilization & ,689 & 1,000 & & & \\
\hline X5 & Technology Utilization & ,664 & ,925 & , 140 & 6,621 & $* * *$ \\
\hline$X 6<\ldots$ & Technology Utilization & ,734 & 1,021 &, 150 & 6,788 & $* * *$ \\
\hline$X 7<\ldots$ & Technology Utilization & ,665 & ,839 &, 132 & 6,362 & $* * *$ \\
\hline
\end{tabular}

Source: Primary data processed, 2019

Based on test results presented in table 3, it appeared that each indicator in ease of use and technology utilization variable has a lambda value or factor loading $>0.50$. So it could be concluded that each of these indicators together presented unidimensionality for ease of use and technology utilization variable.

Based on results presented in Table 3. it appeared that each indicator had a CR value> 1.96 and a significance level $<0.05$, It showed that the indicators indicated a significance of latent factors made up.

2. Confimatory Analysis of Endogenous Variables
At this stage, endogenous confirmatory analysis was carried out on variables of shopping ejoyment and impulse buying. This confirmatory analysis was done to confirm whether the observed variables could reflect analyzed factors, they were shopping enjoyment variable and impulse buying variable. To carry out a confirmatory analysis of endogenous variables, there were two basic tests that must be carried out:

a. Goodness of Fit Test

The results of testing conformity of the model in confirmatory factor analysis of shopping enjoyment variable and impulse buying variable were presented in table 4 below:

Table 4. Appropriateness Test Results of Endogenous Variable

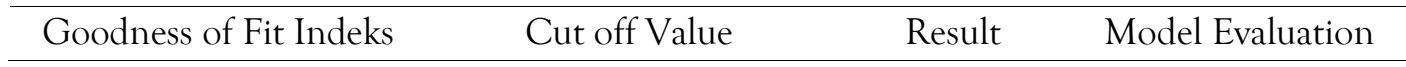


Vol. I, No. I (2019), 47-60

\begin{tabular}{lccc}
\hline Chi-Square $(\mathrm{df}=13)$ & Small $(<22,362)$ & 21,427 & Good \\
Probability & $\geq 0,05$ & 0,065 & Good \\
CMIN/DF & $\leq 2,00$ & 1,648 & Good \\
GFI & $\geq 0,90$ & 0,960 & Good \\
AGFI & $\geq 0,90$ & 0,913 & Good \\
TLI & $\geq 0,95$ & 0,952 & Good \\
CFI & $\geq 0,95$ & 0,971 & Good \\
RMSEA & $\leq 0,08$ & 0,066 & Good \\
\hline
\end{tabular}

Source: Primary data processed, 2019

Table 4 showed that value of Chi Square is 10,528 with a significance level of 0.065 as well as other feasibility values that meet fit criteria, so that it could be concluded that there was no difference between sample covariance matrix and estimated population covariance matrix which was accepted in which it meant that the model is fit. So the model could overall be accepted to provide sufficient confirmation to show that seven indicators used could reflect the latent variables analyzed, they were shopping enjoyment variable and impulse buying variable.

a. Significance Test of Factor Weight

Based on test results presented in Table 4, it could be seen that the indicators on each latent variable had a value of lambda or factor loading which was $>0.50$. So it could be concluded that each of these indicators together presented unidimensionality for each of its latent variable.
Factor weight could be analyzed using t-test which in SEM analysis t-test was identical to Critical Ratio (CR) value. Based on results presented in Table 3, it appeared that each indicator had a CR value> 1.96 and a significance level $<0.05$, it showsed that indicators significantly were a dimension of each latent factor formed.

\section{Full Model Analysis}

Evaluation for suitability of the model proposed in this research was with various goodness-of-fit criteria that had been stated in the previous section. From the model proposed and linked to data, it would be known how the causal relationship between service quality, product quality, customer satisfaction, and customer loyalty was. The results of processing of the proposed model were described below. 
Figure 2. SEM Test Result on Research Model

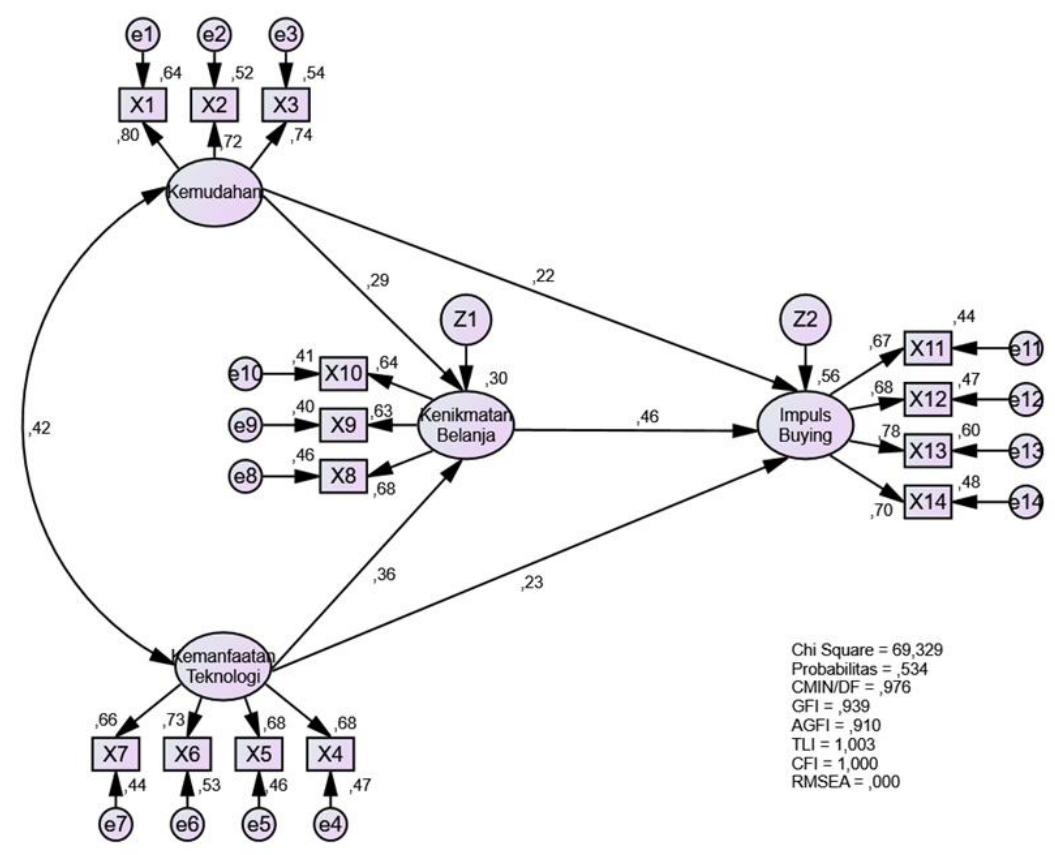

Source : Primary data processed, 2019

the critical value to determine whether the model was good or no, it was summarized in

To determine accuracy of model with the following table. research data, a goodness-of-fit test was tested.

The index of test results was compared with

Table 5. Research Model Assesment of Goodness of Fit

\begin{tabular}{lllc}
\hline Goodness of Fit Indeks & Cut off Value & Result & $\begin{array}{c}\text { Model } \\
\text { Evaluation }\end{array}$ \\
\hline Chi-Square $(\mathrm{df}=71)$ & Small $(<91,670)$ & 69,329 & Good \\
Probability & $\geq 0,05$ & 0,534 & Good \\
CMIN/DF & $\leq 2,00$ & 0,976 & Good \\
GFI & $\geq 0,90$ & 0,939 & Good \\
AGFI & $\geq 0,90$ & 0,910 & Good \\
TLI & $\geq 0,95$ & 1,003 & Good \\
CFI & $\geq 0,95$ & 1,000 & Good \\
RMSEA & $\leq 0,08$ & 0,000 & Good \\
\hline
\end{tabular}

Source : Primary data processed, 2019

Based on result of testing appropriateness model presented in Table 4. above, it showed that the testing criteria overall are in good category or meet the required assessment criteria. In Chi-Square test, a model would be considered with good, if the result showed a 
calculated Chi-Square value which was smaller than Chi Square table value. If the Chi Square count was smaller than value of Chi Square table, it showed that the model was better, there was no difference between estimated population and sample tested. This research model showed that the calculated Chi Square value was 69.3329, while the critical value / Chi Square table with $\mathrm{df}=71$ was 91.670 , so oother index values are also within the expected value range. It meant that this research model was not different from the estimated population / the model which was considered good (accepted), because ChiSquare in this study was smaller than the critical value / table.

\section{Hypothesis Test}

After testing SEM assumptions and model fit, then Hypothesis testing with causality of research variables was tested. Hypothesis test results of relationship among the estimated variables of the Weight Regression value in CR column (identical to t-count) are compared with the critical value (identical to t-table). The critical value for significance level of 0.05 (5\%) was 1.998 (see t-table), while the critical value for significance level $0.1(10 \%)$ was 1.66 (see t-table). If the CR value was more than critical value, then research hypothesis would be accepted. If the CR value was less than critical value, the research was rejected. The regression weight value of relationship among participation variables was in table 6 .

Table 6. Regression Weight

\begin{tabular}{|c|c|c|c|c|c|c|c|}
\hline & & & Std Estimate & Estimate & S.E. & C.R. & $\mathrm{P}$ \\
\hline Shopping_Enjoyment & $<$ & Ease & ,291 & ,270 &, 114 & 2,378 &, 017 \\
\hline Shopping_Enjoyment & $<\ldots$ & Technology_Usefulness & ,359 & ,358 & , 128 & 2,797 & ,005 \\
\hline Impulse_Buying & $<$ & Technology_Usefulness & ,462 & ,428 &, 130 & 3,282 &, 001 \\
\hline Impulse_Buying & $<$ & Ease &, 222 & ,191 & ,094 & 2,019 & ,043 \\
\hline Impulse_Buying & $<\ldots$ & Technology_Usefulness & ,234 & ,216 & , 106 & 2,033 & ,042 \\
\hline
\end{tabular}

Based on data in table 5, we could present

test results on research hypotheses.

1. Hypothesis Test 1

The estimated parameter for testing effect of ease of use on shopping enjoyment showed a CR value of 2.387 with a probability of 0.017. Because CR value generated from calculation was greater than critical value at 0.05 (5\%) significance level of 1.998 and the probability value resulted $(0,000)$ was $<0.05$, it could be concluded that ease of use statistically had a positive and significant effect to shopping enjoyment.

\section{Hypothesis Test 2}

The estimation parameter for testing effect of technology utilization on shopping enjoyment showed a CR value of 2.797 with a probability of 0.005 , because $C R$ value generated from calculation was greater than critical value at $0.05(5 \%)$ significance level of 1.998 and the probability value resulted $(0,000)$ was $<0.05$, it could be concluded that technology utilization variable was statistically proven to have a positive effect and significant to enjoyment of shopping. 


\section{Hypothesis Test 3}

The estimated parameter for testing effect of ease of use on impulse buying showed a CR value of 2.019 with a probability of 0.043 . Because CR value generated from the calculation was greater than critical value at 0.05 (5\%) significance level of 1.998 and the probability value resulted $(0,000)$ was $<0.05$, it could be concluded that ease of use statistically had a positive and significant effect to impulse buying.

\section{Hypothesis Test 4}

The estimation parameter to test importance of benefits of buying impulses showed a CR value of 2.033 with a probability of 0.042 . Therefore CR value generated from calculation was greater than critical value at 0.05 (5\%) significance level of 1.998 and the probability value resulted $(0.042)$ was $<0.05$, so it could be concluded that variable had benefits and significance on impulse buying.

\section{Hypothesis Test 5}

The estimated parameter for testing effect of shopping enjoyment on impulse buying showed a CR value of 3.282 with a probability of 0.001 . Because $\mathrm{CR}$ value generated from calculation was greater than critical value at $0.05(5 \%)$ significance level of 1.998 and the probability value resulted (0.001) was $<0.05$, it could be concluded that variable of shopping pleasure was statistically proven to have a positive and significant effect to impulse buying.

\section{Conclusion}

This research is intended to prove empirically about variables that can explain impulse buying. There are three things that can be concluded from the results of this study, namely:

1. Testing conducted on the variable ease of use and the convenience of shopping shows that the ease of use of information technology has proven to have a significant positive effect on shopping pleasure.

2. Tests conducted on the variable utilization of technology and shopping efficacy indicate that the ease of information technology efficacy has a significant positive effect on shopping pleasure.

3. Testing conducted on the variable ease of use and impulse buying shows that the ease of use of information technology has proven to have a significant positive effect on impulse buying.

4. Tests carried out on the variable technological usefulness and impulse buying show that the usefulness of information technology has proven to have a significant positive effect on impulse buying.

5. Testing conducted on shopping pleasure and impulse buying variables shows that shopping pleasure has a significant positive effect on impulse buying.

This study has proven that consumer interest in the products offered on the online shop site is influenced by the ease and usefulness of information technology, so that it can 
support consumer enjoyment in shopping. Suggestions that can be given based on the results of the analysis are the site manager (Tokopedia) should be more giving a sense comfortable when consumers use the site / application when shopping, that comfort can berealized by updating the appearance of the site / application more interesting, adding more innovative service menus, more pressing the number of complaints consumers who hesitate to convey when complaints occur when shopping, improve the speed of handling problems that occurred during the transaction.

\section{References}

Akram, U., Hui, P., Khan, M. K., Yan, C., \& Akram, Z. (2018). Factors affecting online impulse buying: Evidence from Chinese social commerce environment. Sustainability (Switzerland), 10(2). https://doi.org/10.3390/su10020352

Agung, I. G., \& Sri, K. (2018). Pengaruh Personality Dan Shop Enjoyment Terhadap Impulse Buying Behavior Yang Dimediasi Impulse Buying Tendency Anak Agung Istri Sandya Kharisma 1 Fakultas Ekonomi dan Bisnis Universitas Udayana , Bali , Indonesia Kebutuhan manusia yang paling mendasar ad. 7(6), 3320-3352.

Batra, R., \& Ahtola, O. T. (1991). Measuring the hedonic and utilitarian sources of consumer attitudes. Marketing Letters. https://doi.org/10.1007/BF00436035

Bitner, M. J. (1992). Servicescapes: The Impact of Physical Surroundings on Customers and Employees. Journal of Marketing. https://doi.org/10.2307/1252042

Davis, F. D. (1989). Perceived usefulness, perceived ease of use, and user acceptance of information technology. MIS Quarterly: Management Information Systems, 13(3), 319-339. https://doi.org/10.2307/249008

DR. Richardus Eko Indrajit. (2000). Manajemen sistem Informasi dan Teknologi Informasi. Retrieved from repository.unand.ac.id

Elizabeth Ferrell, M., \& Beatty, S. E. (1998). Impulse buying: Modeling its precursors. Journal of Retailing.

Ferdinand, A. (2006). Structural Equation Modeling Dalam Penelitian Manajemen. Semarang: Badan Penerbit Universitas Diponegoro.

Hart, C., Farrell, A. M., Stachow, G., Reed, G., \& Cadogan, J. W. (2007). Enjoyment of the shopping experience: Impact on customers' repatronage intentions and gender influence. Service Industries Journal. https://doi.org/10.1080/02642060701 411757

Hatane Semuel. (2007). Pengaruh Stimulus Media Iklan, Uang Saku, Usia, Dan Gender Terhadap Kecenderungan Perilaku Pembelian Impulsif (Studi Kasus Produk Pariwisata). Jurnal Manajemen Pemasaran.

I Made Rendy Wicaksana, I. W. S. (n.d.). Pengaruh Persepsi Kemudahan Penggunaan , Kegunaan Yang Dirasakan, Dan Tingkat Pendidikan Terhadap Niat Berbelanja Kembali mengetahui jumlah pengguna internet dua tahun terakhir yaitu dari tahun 2011 hingga Tingkat Pengguna Internet di Indonesia Tahun 201. 2815-2832.

Jogiyanto. (2005). Analisis dan Desain Sistem Informasi. Yogyakarta: Penerbit Andi. 
Mowen, john C., \& Minor, M. (2002). Prilaku konsumen. In Organization. https://doi.org/10.1016/j.materresbull. 2010.09.021

Nakayima, J. K. (2011). Percieved usefulness, percieved easeof use, behavioural intention to use and actual system usage in Centenary Bank (Makerere University). Retrieved from

http://www.dspace.mak.ac.ug/handle/ 10570/2607

Purnasari, A. C., \& Rastini, N. M. (2018). Peran Kenikmatan Berbelanja Dalam Memediasi Kepribadian Terhadap Impulsive Buying. INOBIS: Jurnal Inovasi Bisnis Dan Manajemen Indonesia. https://doi.org/10.31842/jurnalinobis.v1i3.40

Purwa, E. M. R. G., \& Yasa, N. N. K. (2015). Strategi Store Environment Dan Time Pressure Pada Pembelian Impulsif Melalui Emotional State. Jurnal Dinamika Manajemen. https://doi.org/10.15294/jdm.v5i2.365 7

Rook, D. W., \& Fisher, R. J. (1995). Normative Influences on Impulsive Buying Behavior. Journal of Consumer Research.

https://doi.org/10.1086/209452

Schiffman, L., \& Kanuk, L. L. (2008). Perilaku konsumen. Jakarta: Indeks.

Sekaran, U. (2003). Research Methods for Business: A Skill-Building Approach (New York: Wiley \& Sons). In Research Methods for Business: A Skill-Building Approach (New York: Wiley $\mathcal{E}$ Sons). https://doi.org/10.1007/s11227-0100451-x

Setiawan, W. (2017). Era Digital dan
Tantangannya. Seminar Nasional Pendidikan 2017, 1-9.

Thompson, R. L., Higgins, C. A., \& Howell, J. M. (1991). Personal computing: Toward a conceptual model of utilization. MIS Quarterly: Management Information Systems. https://doi.org/10.2307/249443

Verhagen, T., \& van Dolen, W. (2009). Online purchase intentions: A multichannel store image perspective. Information and Management. https://doi.org/10.1016/j.im.2008.12. 001

Very Torgonda Tampubolon, B. P. (2018). Pengaruh Kemudahan Penggunaan Dan Manfaat Terhadap Penggunaan Aplikasi Pertamina Go Di Kota Semarang (Survey Pada Pengguna Apllikasi Pertamina Go Di Kota Semarang). Journal of the Society of Brewing,Japan, 7(3), 477-490. https://doi.org/10.6013/jbrewsocjapan 1915.62.477 
http://journal.walisongo.ac.id/index.php/JDMHI/index http://dx.doi.org/10.21580/jdmhi.2019.1.1.4762 